УДК 351:37.07:316.422

DOI: 10.34132/pard2019.04.03

\title{
ОСНОВНІ НАПРЯМИ ДЕРЖАВНОГО УПРАВЛІННЯ ОСВІТОЮ В УМОВАХ РЕФОРМУВАННЯ
}

Biльхова T.B., канд. екон., наук, доцент КЗВО «Дніпровська академія неперервної освіти», м. Дніпро, Україна

Москалець М.М., канд. пед., наук, доцент, КЗВО «Дніпровська академія неперервної освіти», м. Дніпро, Україна

Рибкіна C.O., аспірант, Дніпровський державний аграрно-економічний університет, м. Дніпро, Україна

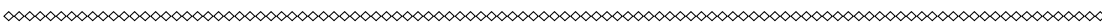

Система освіти покликана сприяти реалізації основних завдань соціально-економічного і культурного розвитку країни. В статті проаналізовано сучасний стан иієї галузі, місце та ї̈ значення в економічі України. Виявлено основні проблеми, які стосуються фахових компетентностей, фінансового забезпечення, недосконалості законодавчої бази та державного регулювання освітньої сфери. Визначено основні напрями державного управління в умовах реформування освіти.

Показано щзо освіта - одна з найважливіших областей, які держава підтримує створенням умов для ї̈ розвитку. Україна запроваджує реформу освіти, яка може змінити якість освітніх послуг, ставлення до престижу педагогічної та наукової діяльності. Проте, в контексті реформ, існує проблема в управлінні иією сферою, оскільки необхідно реагувати на виклики для ї̈ вдосконалення. Система освіти є невід'ємною складовою духовності, яка готує молодь до життя на основі їх знань у дошкільних, середніх, професійнотехнічних та вищих навчальних закладах. Згідно зі статтею 5 Закону України «Про освіту», освіта є державним пріоритетом, який забезпечує інновачійний, сочіальний, економічний та культурний розвиток суспільства. Фінансування освіти - це інвестиції в людський потенціал, сталий розвиток суспільства і держави. 
Наголошено та тому щзо одним з пріоритетних напрямків є реформа економічних основ системи освіти, яка має бути спрямована на створення прозорих фінансово-економічних механізмів цілеспрямованого накопичення та цільового використання коштів, необхідних для повного здійснення конституиійних прав громадян на освіту.

Автор акиентує увагу що реформа економічних основ системи освіти, має бути спрямована на створення прозорих фінансовоекономічних механізмів цілеспрямованого накопичення та иільового використання коштів, необхідни для повного здійснення конституизійних прав громадян на освіту.

Слід також пам'ятати, що автономія - це не лише незалежність, а й відповідальність навчального закладу щзодо прийняття ефективних управлінських рімень щзодо організачії навчального прочесу, господарської діяльності, роботи з персоналом та споживачами освітніх послуг.

Запропонована реформа освіти та науки Украӥни передбачає зміни, які наблизять ї̈ до європейських стандартів, значно підвищать конкурентоспроможність, а також дадуть можливість децентралізачії ї̈ управління.

Ключові слова: державне управління, освіта, реформа, реформування, законодавство, система, органи управління, заклади освіти.

Постановка проблеми у загальному вигляді. Система освіти це найважливіший компонент духовності, яке здійснює підготовку молоді до життя на основі отриманих знань в дошкільних, середніх закладах освіти, професійно-технічних та вищих навчальних закладах. Тому, освіта $є$ однією із найважливіших галузей, якою піклується держава, створюючи умови для ії розвитку. Україна запроваджує освітню реформу, яка зможе змінити якість надання освітніх послуг, ставлення до престижності педагогічної та наукової діяльності. Згідно статті 5 Закону України «Про освіту», освіта $\epsilon$ державним пріоритетом, що забезпечує інноваційний, соціально-економічний і культурний розвиток суспільства. Фінансування освіти є інвестицією в людський потенціал, сталий розвиток суспільства і держави [1]. 
Сьогодні Україна обирає шлях до європейських стандартів освітнього процесу. Однак, через успадковану радянську адміністративнокомандну систему поняття розвитку демократичності втрачає своє значення і відбувається підміна понять. Тому, в умовах реформування, виникає проблема в управлінні цією сферою, проте і чинні механізми управління із запізненням реагують на ситуації, що складаються. Актуальність дослідження цих питань полягає в становленні балансу між учасниками освітнього процесу, потребами ринку праці в країні та розробки механізмів управління системою освіти в цілому.

Аналіз останніх досліджень та публікацій. Формування та реалізація державної політики у сфері освіти, зокрема аспекти управління освітою, досліджується в наукових працях Л. Гаєвської, Д. Дзвінчука, С. Крисюка, С. Кнішнік, В. Лугового, Т. Лукіної, В. Сиченка та ін. Особливості управління діяльністю вітчизняних вищих закладів освіти трактуються у виданнях В. Фадєєва, В. Крижка та В. Паскар, Т. Шаравари, Л. Зеленської, С. Золотухіної та ін. Щодо взаємовідносин вищих навчальних закладів із органами місцевої влади, концепції менеджменту освіти розкрито у працях О. Антонюка, Т. Шушари, С. Кузьміної. У теорії державного управління освітою проблему досліджували: О. Матвієнко, О. Мещанінов та ін.

Проте залишається не дослідженим питання, щодо основних напрямів державного управління освітньою діяльністю в умовах реформування.

Формулювання цілей статті (постановка завдання). Враховуючи сучасний стан та значення системи освіти в Україні, метою статті є визначення та удосконалення механізмів державного регулювання цієї сфери.

Виклад основного матеріалу дослідження. Освіта в України є широко розгалуженою, взаємоузгодженою, комплексною системою, яка динамічно розвивається та якісно модернізується під впливом низки факторів, які тісно пов'язані з загальною економічною та політичною ситуацією в країні. Освітнє виробництво визначається широким асортиментом послуг: виховних, освітніх, наукових. Освітня послуга - це комплекс навчальної і наукової інформації, що створюється у процесі діяльності педагогічного колективу закладу освіти 
і передається учню, студенту у вигляді суми знань загальноосвітнього та професійного характеру, для подальшого застосування. Освітні послуги забезпечують найбільш продуктивне задоволення потреб: особистості - в освіті; навчального закладу - у конкурентоспроможності на ринку і матеріальному добробуті його працівників; організацій - в розвитку персоналу; суспільства - у розширеному відтворенні трудового й освітнього потенціалу країни.

Освітня послуга має суттєву специфіку. По-перше, надання послуги є форвардною операцією, адже надають не стільки послугу, скільки іiі результат, який залежить не лише від учителя але й від учня. Подруге, освітню послугу неможливо зберігати (з позиції виробника). По-третє, право власності на освіту не є визначеним. Освіта, з одного боку, це власність самої людини, а $з$ іншого - це інтелектуальна власність суб' єкта освітньої послуги (автора методики, навчального закладу, держави тощо). Також до особливостей освітньої послуги слід віднести:

- високу собівартість;

- відносну тривалість виробництва;

- творчий зміст процесу використання;

- відтермінованість ефекту від отриманих знань;

- колективне споживання;

- вплив як на окрему людину, так і на суспільство в цілому;

- виробництво системою «учитель - учень» не дозволяє чітко визначити внесок кожного у спільний результат [17, с. 50,51].

Узагальнюючи підходи до освіти необхідно відмітити, що сучасна діяльність у педагогіці здійснюється тріадою менеджмент-маркетинг-інновації. Внутрішнім завданням кожного менеджера закладу освіти $є$ необхідність спроектувати й підтримувати таке середовище, в якому люди, що працюють спільно, вмотивовані діяти продуктивно й ефективно в напрямку досягнення групових цілей для того, щоб:

- заклад мав свої переваги;

- давав якісну освіту;

- iї любили учні, цінували батьки, студенти, слухачі;

Крім того, найголовнішим для оцінки діяльності закладу освіти $\epsilon$ конкурентоспроможність випускників школи в незалежному оці- 
нюванні та подальшому навчанні. Стратегічним завданням державної освітньої політики нашої країни є висока конкурентоспроможність української освіти на ринку світових освітніх послуг та повне поглиблення у міжнародне співробітництво. Державне управління освітою - це діяльність органів влади, яка спрямована на організацію, планування та контроль освітньої діяльності, з метою забезпечення населення якісними освітніми послугами та доступності до освіти впродовж життя.

У розвинутих країнах питання освіти посідає одне з провідних місць у соціально- економічному середовищі. В таких країнах державний вплив на цю сферу має яскраво виражений економічний характер, тому постійно виділяються значні фінансові ресурси. Тобто, ці країни щорічно збільшують державні видатки на освіту, таким чином фінансуючи та інвестуючи у свій майбутній розвиток. Тобто, чим краща освітня підготовка населення, тим значніша їх роль у суспільному виробництві. Держава розробляє стратегію економічного зростання, що вирішує соціальну проблему, пов'язану із безробіттям, бідністю, злочинністю, низьким рівнем життя. Для прикладу, в Австралії, Швеції, Норвегії та Чехії, рівень витрат на заробітну плату та комунальні платежі у загальній структурі видатків на вищу освіту не перевищує $60 \%$.

Фінансування сфери освіти в Україні суттєво відрізняється від передових європейських та західних країн. Провідними джерелами вітчизняного фінансування є бюджет та самофінансування за рахунок ресурсів суб' єктів господарювання та домогосподарств. Не можна не погодитися з Олієвською М.Г., яка зазначає, що «...фінансування освіти в Україні за рахунок коштів державного бюджету залежить від збалансованості бюджету; ефективності використання коштів, контингенту тих, хто навчається» $[13$, с. 17]. Певною особливістю вітчизняного бюджетного фінансування освіти $€$ i те, що більша частина коштів використовується не на підвищення якості освітніх послуг, а на поточні господарські потреби, що також знижує ефективність такого фінансування. Аналізуючи статистичні дані фінансування нашої країни за період 2007-2016 рр., бачимо що, є поступове і помітне збільшення видатків майже на 87 млрд. грн. (рис. 1). 
«Public Administration and Regional Development»

https://pard.mk.ua/index.php/journal

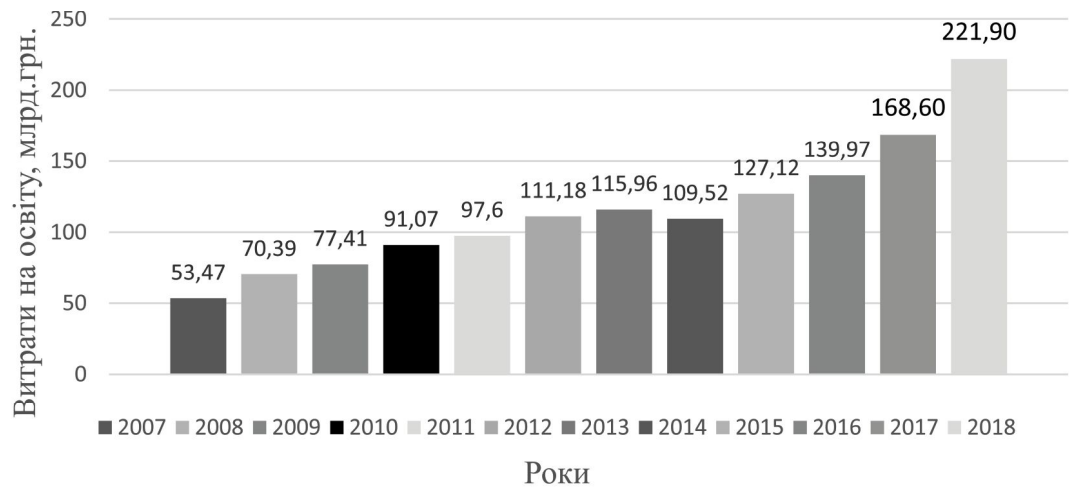

Рис. 1. Загальні витрати на освіту в Україні за період 2007-2016 pp.

Джерело: [8, с. 5; 26].

Проте, відсоток обсягу ВВП на освіту поступово зменшується., що перш за все пояснюється зростанням курсу долара. Так у 2016 році порівняно з 2007 роком відсоток обсягу ВВП зменшився на 1 в.п, у 2007 році курс долара становив 5,05 грн за 1 долл., а у 2016 році відповідно 25,55 (рис. 2).

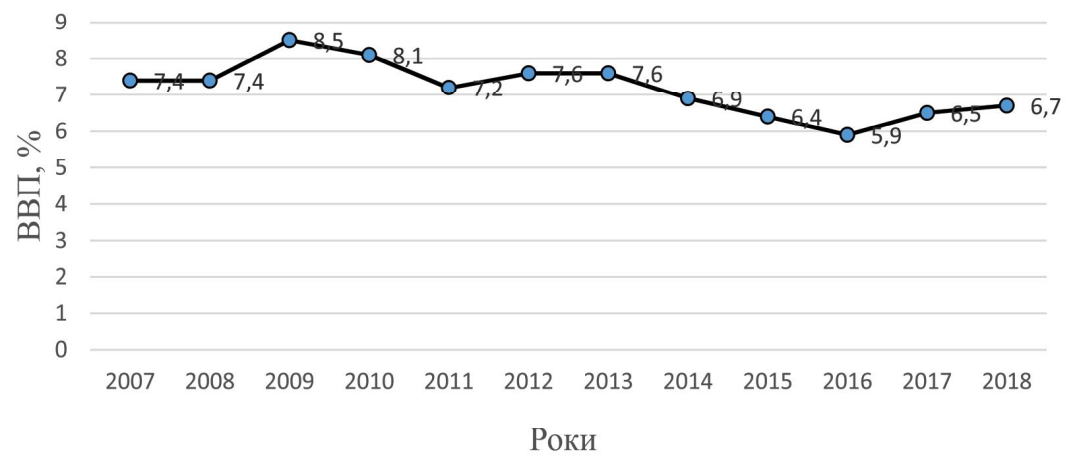

Рис. 2. Витрати валового внутрішнього продукту, \% Джерело: [8, с. 5; 26].

Метод визначення обсягів фінансування (а саме нормативний), який використовується як спосіб розподілу державних коштів, до- 
зволяє корегувати їх в бік зниження у зв’ язку з нестачею. Тому обсяги витрат на освіту, незважаючи на тенденцію до зростання, значно менші ніж аналогічні показники розвинутих країн.

У 2015 році відбулися зміни у порядку фінансування освіти, 3 того часу, є можливість забезпечити рівне фінансування всіх закладів освіти регіону за рахунок коштів місцевих бюджетів та державних субвенцій. В таблиці 1 подана інформація про використання освітньої субвенції місцевими бюджетами у першому півріччі 2017 та 2018 роках.

Таблиця 1

\section{Кошти освітньої субвенції в першому півріччі 2017 і 2018 рр. (млрд. грн.)}

\begin{tabular}{|l|c|c|c|c|}
\hline \multicolumn{1}{|c|}{ Показник } & $\mathbf{2 0 1 7}$ & $\mathbf{2 0 1 8}$ & $\begin{array}{c}\text { Відхилення } \\
\mathbf{2 0 1 7 - 2 0 1 8}\end{array}$ & $\begin{array}{c}\text { Відхилен- } \\
\text { ня (\%) }\end{array}$ \\
\hline Планові значення & 31,2 & 36,8 & 5,6 & 18,0 \\
\hline Фактичні видатки & 28,7 & 34,5 & 5,7 & 20,0 \\
\hline Рівень використання коштів, \% & 92,0 & 93,8 & 1,8 в.П. & $\mathrm{X}$ \\
\hline
\end{tabular}

[Джерело: 14].

Плановий обсяг освітньої субвенції в першому півріччі 2018 року порівняно з цім же періодом 2017 року збільшився на 5,6 млрд. грн. (18\%). Збільшення субвенції у 2018 році пояснюється в першу чергу, тим що, змінено формулу іiі розподілу, яка здійснюється на підставі:

- розрахункового показника фінансового нормативу бюджетної забезпеченості;

- контингентна учнів усіх типів закладів загальної середньої освіти станом на 5 вересня року, що передує поточному бюджетному періоду;

- контингента учнів закладів професійної (професійно-технічної) освіти станом на 1 січня року, що передує плановому бюджетному періоду, та контингента студентів станом на 1 жовтня року, що передує плановому бюджетному періоду;

- навчального плану; 
- заробітної плати вчителя;

- коригуючих коефіцієнтів [14].

Таке ставлення, необхідно удосконалити або розробити підхід до визначення обсягів фінансування із врахуванням мінімальних соціальних стандартів, які дозволять встановити нижню межу обов'язкового фінансового забезпечення розвитку освіти. Державна політика у цьому напрямку повинна бути націлена на забезпечення доступності освіти для соціально незахищених верств населення, надаючи гарантований якісний результат знань. Як стверджують Вербицька А.В. та Петрик О.Л. «... кожна країна повинна знайти відповідний баланс між рівнем фінансування, доступності та якості вищої освіти» [11, с. 35].

Окрім проблем фінансування, постає питання у забезпеченні закладів освіти матеріально-технічним оснащенням, ефективним управлінням та якісним менеджментом, координацією та підтримкою органів державного управління. Проте, стан матеріально-технічної бази освітніх закладів країни знаходиться на недостатньому рівні. Наприкінці 2016 року було проведене дослідження Урядовим контрактним центром, яке стосувалося проблем шкільної освіти. Було виявлено, що вітчизняним школам гостро бракує сучасних комп'ютерних засобів, оснащених кабінетів мультимедійними засобами та шкільних автобусів. Опитування громадян, а саме 1025 респондентів показало, що 31,9\% нарікають на невідповідний стан шкіл та їх матеріальне технічне обладнання; 17,1% невдоволені закриттям частини шкіл. Найголовнішою проблемою в сільській місцевості $\epsilon$ відсутність якісних сучасних підручників та навчальних матеріалів. Нові стандарти початкової школи, пропонують вивчення іноземної мови 3 першого класу й покращення умов навчання. «Стандарти запровадили, вказівка пішла, а забезпечити запроваджене - забули, i вкотре вчителі своїми силами втілюють міністерські новації: обладнують класи, фарбують інвентар», шукають вчителів іноземної мови для найменших. Це ще раз підтверджує, що сучасна українська освіта потребує цілеспрямованого втручання та істотних змін [2].

Деякі освітні заклади розташовуються в пристосованих приміщеннях, що не відповідають санітарно-гігієнічним нормам, у них 
відсутні необхідні засоби навчання, недостатнім чином обладнанні сучасні кабінети та лабораторії для проведення наукових досліджень. Відповідно, це призводить до зниження якості надання освітніх послуг. Тому, перед місцевими владами постає завдання у створенні, координації та контролю спеціальних програм матеріально-технічного забезпечення навчальних закладів усіх рівнів, які дозволять:

- побудувати та оновити нові освітні заклади;

- створити умови для доступності учнів, студентів, слухачів до якісної освіти;

- модернізувати матеріально-технічну, навчально-методичну бази освітніх закладів, які відповідають сучасним вимогам;

- покращити умови перебування споживачів освітніх послуг у цих закладах.

Сучасне освітнє середовище, повинне забезпечити необхідні умови, засоби і технології для навчання учнів, освітян, батьків, які покладаються на співпрацю зі школою та взаєморозуміння.

Реформа освіти та науки України передбачає зміни, які стосуються усіх ланок цієї галузі (табл. 2).

Таблиця 2

\section{Основні зміни в системі освіти і науки України, які передбачені реформою}

\begin{tabular}{|l|l|}
\hline \multicolumn{1}{|c|}{ Рівні освіти } & \multicolumn{1}{c|}{ Зміни } \\
\hline Середня & - нова суть та мета освіти, спрямована на фор- \\
& мування ключових компетентностей; \\
& - новий статус учителя, який володіє сучасними \\
& методиками викладання і який професійно реа- \\
& лізує педагогіку партнерства; \\
& - сучасна система управління та адмініструван- \\
& ня шкіл, а саме керівник - менеджер освіти; \\
& - нова система контролю якості освіти. \\
\hline
\end{tabular}


Продовження табл. 2

\begin{tabular}{|l|l|}
\hline Професійно-техніч- & - багатоканальне фінансування; \\
на & створення закладів нового типу - регіональних \\
& центрів професійної підготовки, що сприятиме \\
збільшенню мережі закладів; & - осучаснення змісту професійно-технічної осві- \\
ти; & - створення регіональних рад професійної осві- \\
ти.
\end{tabular}

Джерело: [7].

Кабінет міністрів України ухвалив Концепцію реалізації державної політики у сфері реформування загальної середньої освіти «Нова українська школа» на період до 2029 року. Згідно даної Концепції було визначено основні проблеми сучасної середньої освіти, мету та основні шляхи і способи їх розв'язання.

Освітня реформа пропонує першочергові зміни в середній освіті які сконцентровані на детиноцентризмі та ключових компетентностях учня, якими він повинен володіти, а саме: вільне володіння державною мовою, здатність спілкуватися іноземними мовами, 
математична, загальнокультурна та екологічна компетентності, інноваційність, навчання впродовж життя, громадянські та соціальні компетентності, підприємливість та фінансова грамотність.

Це можна представити у вигляді особистісно-орієнтованої моделі освіти, в центрі якої є особистість учня, а саме його:

- потреби;

- мотиви;

- попередній досвід;

- здібності;

- активність;

- інтелект;

- індивідуально-психологічні особливості;

- ціннісні орієнтири.

Формула нової української школи складається 3 дев’яти ключових компонентів, які пояснюють иї сутність (табл. 3 ).

Таблиця 3

\section{Структура Концепції Нової української школи}

\begin{tabular}{|l|l|}
\hline Формула НУШ & \multicolumn{1}{|c|}{ Дев’ять ключових компонентів } \\
\hline Ключові & - Дитині недостатньо дати лише знання, ще важливо \\
для життя & навчити користуватися ними; \\
& $\begin{array}{l}\text { - Знання та вміння, взаємопов’язані з ціннісними орі- } \\
\text { єнтирами учня, формують його життєві компетент- } \\
\text { ності, потрібні для успішної самореалізації у житті, } \\
\text { навчанні та праці }\end{array}$ \\
\hline Педагогіка & $\begin{array}{l}\text { Кожна дитина - неповторна, наділена від природи } \\
\text { пнікальними здібностями, талантами та можливостя- } \\
\end{array}$ \\
& $\begin{array}{l}\text { ми; } \\
\text { Місія нової української школи - допомогти роз- } \\
\text { крити та розвинути здібності, таланти і можливості } \\
\text { кожної дитини на основі партнерства між учителем, } \\
\text { учнем і батьками }\end{array}$ \\
\hline
\end{tabular}


Продовження табл. 2

\begin{tabular}{|c|c|}
\hline $\begin{array}{l}\text { Умотивований } \\
\text { учитель }\end{array}$ & $\begin{array}{l}\text { - Новій школі потрібен новий учитель, який стане } \\
\text { агентом змін; } \\
\text { - Передбачено ряд стимулів для особистого і профе- } \\
\text { сійного зростання, щоб залучити до професії найкра- } \\
\text { щих }\end{array}$ \\
\hline $\begin{array}{l}\text { Орієнтація на } \\
\text { учня }\end{array}$ & $\begin{array}{l}\text { - НУШ працюватиме на засадах особистісно-орієн- } \\
\text { тованої моделі освіти; } \\
\text { - Школа максимально враховуватиме права дитини, їі } \\
\text { здібності, потреби та інтереси, на практиці реалізую- } \\
\text { чи принцип дитиноцентризму }\end{array}$ \\
\hline $\begin{array}{l}\text { Виховання на } \\
\text { цінностях }\end{array}$ & $\begin{array}{l}\text { - НУШ формуватиме ціннісні ставлення й судження, } \\
\text { що слугують базою для щасливого особистого життя } \\
\text { та успішної взаємодії з суспільством }\end{array}$ \\
\hline $\begin{array}{l}\text { Нова структура } \\
\text { школи }\end{array}$ & $\begin{array}{l}\text { - Реформа передбачає суттєву зміну структури се- } \\
\text { редньої школи, щоб максимально врахувати фізичні, } \\
\text { психологічні, розумові здібності дитини кожної віко- } \\
\text { вої групи }\end{array}$ \\
\hline $\begin{array}{l}\text { Автономія } \\
\text { школи і якість } \\
\text { освіти }\end{array}$ & $\begin{array}{l}\text { - Вільну людину може сформувати лише вільна осо- } \\
\text { бистість; } \\
\text { - Нова школа матиме широку автономію }\end{array}$ \\
\hline $\begin{array}{l}\text { Справедливе } \\
\text { фінансування і } \\
\text { рівний доступ }\end{array}$ & $\begin{array}{l}\text { - У новій школі публічні фінанси розподілятимуть } \\
\text { прозоро, щоб відстежувати результати освітніх ін- } \\
\text { вестицій }\end{array}$ \\
\hline $\begin{array}{l}\text { Сучасне освітнє } \\
\text { середовище }\end{array}$ & $\begin{array}{l}\text { - Творче середовище буде організоване в новій школі; } \\
\text { - Зміні підлягають як фізичне просторово-предметне } \\
\text { оточення, так і програми та засоби навчання }\end{array}$ \\
\hline
\end{tabular}

[Джерело: 16]

Підсилюється висока роль учителя як партнера у вихованні особистості, що збільшує авторитет сучасного педагога. Змінюється роль і відповідальність керівника школи, який повинен критично мислити, запроваджувати проектну діяльність, підтримувати педагогічне партнерство у закладі (між батьками, учнями та вчителями), 
прозоро використовувати кошти та постійно звітувати про їх використання, забезпечувати імідж закладу «Розробка стратегії розвитку закладу загальної середньої освіти повинна обов'язково включати в себе ряд інноваційних маркетингових інструментів, що здатні забезпечити у майбутньому стійку конкурентоспроможність, високу адаптивність до зовнішнього середовища, якість отриманих знань, вмінь, навичок та компетенцій, а також високу мобільність як педагогічних працівників, так і учнів» [10, с. 59]. Дуже важливим покращенням є створення Державної служби якості освіти, головною метою якої є рекомендації, а не санкції.

Важливе і пріоритетне завдання освітньої реформи полягає у створенні такої школи, де дітям приємно навчатися, де отримують не лише знання, а й уміння практично застосовувати їх у житті. Тому вчитель Нової української школи повинен організувати компетентнісне навчання (не знання заради знань, а вміння застосовувати їх в реальному житті, не знати, а вміти користуватися знаннями). Ані для кого не секрет, що можна закінчити середню школу на «відмінно», знати та вміти все, що вона вимагає, але так і не стати «розумною людиною», тобто людиною, готовою ефективно й адекватно діяти в різних життєвих ситуаціях.

Після завершення навчання у середній школі, близько 70 \% учнів України вступають до вищих навчальних закладів. Для прикладу, у країнах Західної Свропи цей показник не перевищує 50 \%. Проте, кількість не завжди означає якість. Велика кількість колишніх школярів банально не готова до університетського навчання. Тому реформування закладів професійно-технічної освіти передбачає їх збільшення та якісне оснащення сучасним обладнанням та новими освітніми технологіями, які забезпечать здобуття якісної професійної підготовки. 3 цією метою заклади професійно-технічної освіти у 2017 році почали фінансуватися із обласних бюджетів та бюджетів міст-обласних центрів. Важлива роль відводиться радам професійної освіти, до складу яких входять представники місцевої влади, роботодавців, закладів освіти та громадських організацій.

У вищій освіті створюється Національне агентство із покращення якості вищої освіти, який забезпечить зовнішній контроль у 
цій ланці. Для підтримки академічної доброчесності створюється Національний репозитарій академічних текстів, який є дієвим інструментом виявлення плагіату і певним ресурсом для обміну інформацією між науковцями. Утворення Національної ради з питань розвитку науки і технологій дає змогу приймати стратегічні рішення щодо державної політики в науково-дослідній сфері. А створення Національного фонду досліджень та формування органів його управління дає можливість науковцям та дослідникам на конкурсній основі отримувати додаткові кошти для здійснення конкретних наукових проектів.

Поряд 3 реформуванням освіти, урядом запропонована Стратегія реформування державного управління України на період до 2021 року. Згідно з цим документом «...Зниження адміністративного навантаження державного регулювання, покращення якості надання адміністративних послуг, забезпечення законності та передбачуваності адміністративних дій покращує позиції держави у світових рейтингах конкурентоспроможності. Крім того, ефективна система державного управління є однією з основних передумов демократичного врядування, що грунтується на принципах верховенства права» [6]. Саме протягом усіх років незалежності Україна у сфері державного управління не відповідала ефективним європейським практикам взаємовідносин між державною владою і місцевим самоврядуванням, через підпорядкованість місцевих державних адміністрацій одночасно декільком цим органам.

Конституція України не надає місцевим органам управління повноважень саме у сфері освіти, але їх визначає Закон України «Про місцеві державні адміністрації». Хоча зміст цих повноважень визначався попереднім Законом України «Про освіту» [2]. Зокрема, стаття 11 зараховувала до органів управління освітою «місцеві державні адміністрації і органи місцевого самоврядування, а також утворені місцевими державними адміністраціями та органами місцевого самоврядування структурні підрозділи з питань освіти (місцеві органи управління освітою)». Частина 1 статті 14 цього Закону надавала повноваження місцевим органам виконавчої влади та органам місцевого самоврядування в освітній сфері, а частина 2 цієї статті 
визнавала необхідність створення відповідних органів управління освітою та визначала їх повноваження. До них належали:

- управління навчальними закладами, що $\epsilon$ комунальною власністю;

- вдосконалення професійної кваліфікації педагогічних працівників, їх перепідготовка та атестація;

- координація дій педагогічних, виробничих колективів, сім'ї, громадськості з питань навчання і виховання дітей;

- контроль за дотриманням вимог щодо змісту, рівня і обсягу освіти, атестація навчальних закладів, що є комунальною власністю.

В цій статті також відмічалося, що «місцеві органи управління освітою у здійсненні своїх повноважень підпорядковані місцевим органам виконавчої влади, органам місцевого самоврядування та відповідним державним органам управління освітою».

Стаття 15 цього документу надавала місцевим органам управління освітою повноваження приводити освітні послуги у відповідність державним стандартам і вимогам шляхом ліцензування, інспектування, атестації та акредитації навчальних закладів у порядку, встановленому Кабінетом Міністрів України, а також приймати рішення про створення, реорганізацію або ліквідацію навчальних закладів.

Закон України «Про загальну середню освіту» у статті 9 частині 5 надавав місцевим органам управління освітою додаткові повноваження, зокрема, затверджувати статути державних та комунальних загальноосвітніх навчальних закладів та здійснювати державний нагляд (контроль) у галузі загальної середньої освіти разом 3 центральним органом виконавчої влади, що реалізує державну політику у сфері освіти (стаття 40, частина 2) [3].

Закон України «Про дошкільну освіту» надавав цим органам такі додаткові повноваження:

- погодження статутів закладів дошкільної освіти незалежно від підпорядкування, типу і форми власності (стаття 13, частина 2);

- здійснення державного контролю за діяльністю дошкільних навчальних закладів разом із центральним органом виконавчої влади, що реалізує державну політику у сфері освіти (стаття 21, частина 2); 
- керівництво підпорядкованими ним методичними кабінетами та іншими науково-методичними установами (стаття 25) [4].

Закон України «Про освіту», який набрав чинності у 2017 році, надає повноваження здійснювати державний нагляд (контроль) в освітній діяльності Центральному органу виконавчої влади для забезпечення якості освіти та його територіальним підрозділам. 3 огляду на таку ієрархію органів виконавчої влади, пріоритетність у прийнятті управлінських рішень має бути наданий саме цьому органу.

Відповідно до пункту 3 статті 22 Закону України «Про місцеві державні адміністрації», вони здійснювали загальне керівництво освітніми закладами, які належали до сфери їх впливу. А новий Закон України «Про освіту» призвів до ліквідації таких закладів. Таким чином місцеві ради можуть делегувати відповідним державним адміністраціям свої повноваження 3 управління закладами освіти лише в тих межах, які вони мають самі [5].

Це зовсім інші повноваження, ніж ті, що надавав попередній Закон місцевим органам управління освітою. Насамперед, вони тепер мають лише повноваження засновника з питань управління закладами освіти, які визначаються частина 2 статті 25. Частина 3 цієї статті забороняє засновникам або уповноваженим ним особам «втручатися в діяльність закладу освіти, що здійснюється ним у межах його автономних прав, визначених законом та установчими документами».

Отже, система управління освітою на місцевому рівні має істотно змінитися в найближчий час. Ці зміни повинні привести повноваження місцевих органів управління у відповідність до чинного Закону України «Про освіту», що може змінити не лише їх функції, але і структуру. Зокрема, можна прогнозувати передачу повноважень $з$ державного нагляду (контролю) за дотримання законодавства у сфері освіти від місцевих державних адміністрацій до територіальних підрозділів Державної служби якості освіти. Також можна прогнозувати створення самостійних підрозділів при органах місцевого самоврядування, що будуть виконувати функції засновника закладів освіти. При цьому може бути відмова органів самоврядування від делегування окремих інших функцій місцевим державним адміністраціям. 
Висновки. Прийняття нового Закону України «Про освіту» наближає цю сферу до європейських стандартів, що значно підвищує конкурентоспроможність закладів освіти та науки, а також дає можливість децентралізації управління системи освіти, створивши умови для партнерства державних органів та навчальних закладів.

В контексті вищевикладеного, одним із пріоритетних напрямів $€$ реформування економічних засад системи освіти, яке має спрямовуватися на створення прозорих фінансово-економічних механізмів цільового накопичення та адресного використання коштів, необхідних для реалізації в повному обсязі конституційних прав громадян на освіту.

Потрібно також пам'ятати, що автономія це не лише самостійність і незалежність, а й відповідальність закладу освіти у прийнятті ефективних управлінських рішень щодо організації освітнього процесу, економічної та господарської діяльності, роботи з кадрами та із споживачами освітніх послуг.

У рамках подальшого реформування державного управління і місцевого самоврядування варто усунути суперечності між законами і вилучити 3 них дублювання функцій, а також невластиві повноваження місцевих державних адміністрацій і органів місцевого самоврядування з управління закладами освіти.

\section{Стаття надійшла до редакціi: 14.02.2019}

\section{MAIN DIRECTIONS OF PUBLIC EDUCATION MANAGEMENT IN REFORMING CONDITIONS}

Tetyana Vilkhova, Associate Professor of the Department of Educational Management, State Policy and Economics, PhD in Economics, CINE "Dniprovska Academy of Continuing Education" Dnipro, Ukraine

Mikhailo Moskalets, Associate Professor of the Department of Public Administration and Law, PhD in Pedagogy, CINE "Dniprovska Academy of Continuing Education" Dnipro, Ukraine 
Svetlana Rybkina, PhD student of the Department of Management, Public Administration and Administration, Dnipro State Agrarian Economic University Dnipro, Ukraine

The article defines the main directions of public administration in the context of reforming education in Ukraine. The current state of this industry, place and its importance in the national economy are analyzed. The main problems, which are related to professional competencies, financial support, imperfect legislative base and state regulation of educational sphere, are revealed. The proposed reform of education and science of Ukraine provides for changes that will bring it closer to European standards, significantly enhance competitiveness as well as give decentralization of its management.

Education is one of the most important areas that the state supports creating conditions forits development. Ukraine introduces an educational reform that can change the quality of educational services, the attitude to the prestige of pedagogical and scientific activity. However, in the context of reform, there is a problem in the management of this area, since it is necessary to respond challenges for its improvement. The educational system is an essential component of spirituality, which prepares young people for life on the basis of their knowledge in preschool, secondary education, vocational and higher education institutions. According to Article 5 of the Law of Ukraine "On Education", education is a state priority, which provides innovative, social, economic and cultural development of society. Financing education is an investment in human potential, sustainable development of society and the state.

Today, Ukraine focuses on European standards in the educational process. However, due to the legacy of the Soviet administrativecommand system, the concept of the development of democracy loses its meaning and there is a substitution of concepts. The existing latent control mechanisms respond to emerging situations. Therefore, the relevance of the study of this topic is that it is necessary to develop mechanisms for managing the development of education to establish a balance between the participants of the educational process and the needs of the labor market (the economy as a whole). 
One of the priority areas is the reform of the economic foundations of the educational system, which should aim at creating transparent financial and economic mechanisms for targeted accumulation and targeted use of funds necessary for the full implementation of the constitutional rights of citizens to education.

One of the priority areas is the reform of the economic foundations of the educational system, which should aim at creating transparent financial and economic mechanisms for targeted accumulation and targeted use of funds necessary for the full implementation of the constitutional rights of citizens to education.

It should also be remembered that autonomy is not only independence, but also the responsibility of the educational institution in taking effective management decisions regarding the organization of educational process, economic activity, work with staff and consumers of educational services.

In the framework of the further reformation of public administration and local self-government, it is necessary to eliminate the contradictions between the laws and remove duplication of functions from them as well as the inadequate powers of local state administrations and local selfgovernment bodies to manage educational institutions.

Keywords: public administration, education, reform, reform, legislation, system, government, educational institutions

\section{Received: 14.02.2019}

\section{References}

1. Pro osvitu / Zakon Ukrainy vid 05.09. 2017. 2145-VIII - VR. [On education 05.09.2017. 2145-VIII - VR]. Vidomosti Verkhovnoi Rady Ukrainy. Retrieved from: http://zakon.rada.gov.ua/laws/show/2145-19.

2. Pro osvitu / Zakon Ukrainy vid 05.09. 2017. 2145-VIII - VR. [On education 05.09.2017. 2145-VIII - VR]. Vidomosti Verkhovnoi Rady Ukrainy. Retrieved from: http://zakon.rada.gov.ua/laws/show/2145-19.

3. Pro zagalnu serednyu osvitu / Zakon Ukrainy vid 13 05. 1999. 651-XIVVR. [On General Secondary Education 13 05. 1999. 651-XIV-VR]. Vidomosti 
Verkhovnoi Rady Ukrainy. Retrieved from: http://zakon2.rada.gov.ua/laws/ show/651-14/ed20170305.

4. Pro doshkilnu osvitu / Zakon Ukrainy vid 11.07. 2001. 2628-III - VR. [On Pre-school education 11.07. 2001. 2628-III - VR]. Vidomosti Verkhovnoi Rady Ukrainy. Retrieved from: http://zakon2.rada.gov.ua/laws/show/2628-14/ ed20160101.

5. Pro mistsevi derzhavni administratsiyi / Zakon Ukrainy 09. 04. 1999. 586-XIV-VR. [On Local State Administrations 09. 04. 1999. 586-XIV--VR]. Vidomosti Verkhovnoi Rady Ukrainy. Retrieved from: http://zakon2.rada.gov. ua/laws/show/586-14.

6. Sychenko V.V. (2008). Udoskonalennya informatsiyno-komunikativnoyi sistemi mizh derzhavoyu ta suspilstvom $\mathrm{v}$ protsesi reformuvannya vischoyi osviti / V.V. Sychenko. - Derzhava ta regioni : Seriya «Derzhavne upravlinnya» \# 3. p. 186-190.

7. Reforma osviti ta nauki / Uryadoviy portal. Retrieved from: http://www. kmu.gov.ua/ua/diyalnist/reformi/reforma-osviti.

8. Natsionalni rahunki osviti Ukrayini u 2016 rotsi: Statistichniy zbirnik. K.: Derzhavna sluzhba statistiki Ukrayini, 2018. - p. 103.

9. Krisyuk S.V. (2009). Derzhavne upravlinnya osvitoyu: navch. posib. dlya sluhachiv, asp., doktorantiv spets. "Derzhavne upravlinnya osvitoyu" / S. V. Krisyuk. - K.: NADU. - p.220.

10. Vilkhova T.V. (2019). Zastosuvannya marketingovih instrumeniv u zakladah zagalnoyi serednoyi osviti / T.V. Vilkhova, Yu.M. Mogila // Ekonomika ta derzhava. \# 5. - p. 57-59.

11. Verbitska A.V. (2018). Udoskonalennya mehanizmiv derzhavnogo upravlinnya dlya rozkrittya potentsialu integrovanoyi modeli konkuretnospromozhnoyi vischoyi osviti v Ukrayini / A.V. Verbitska, O.L. Petrik // Derzhava ta regioni. \# 2 (62). - p. 34-39.

12. Pro shvalennya Kontseptsiyi realizatsiyi derzhavnoyi politiki u sferi reformuvannya zagalnoyi serednoyi osviti "Nova ukrayinska shkola" na period do 2029 roku / Rozporyadzhennya Kabinetu Ministriv Ukrayini; Kontseptsiya vid 14.12.2016 \# 988-r Retrieved from: http://zakon.rada.gov.ua/laws/show/9882016-r

13. Olievska M.G. (2018). Finansuvannya osviti v konteksti vidtvorennya lyudskogo kapitalu / M.G. Olievska // Naukoviy visnik Uzhgorodskogo natsionainogo universitetu. Vol. 17, part. 2. - p. 16-19.

14. Formula rozpodilu osvitnoyi subventsiyi mizh mistsevimi byudzhetami / Ministerstvo osviti I nauki Ukrayini Retrieved from: http://mon.gov.ua/ua/ 
osvita/zagalna-serednya-osvita/formula-rozpodilu-osvitnoyi-subvenciyi-mizhmiscevimi-byudzhetami

15. Aktualni problemi shkIlnoyi osviti $\mathrm{v}$ Ukrayini / Uryadoviy kur'r Retrieved from: http://ukurier.gov.ua/uk/articles/aktualni-problemi-shkilnoyiosviti-v-ukrayini/

16. Pro Kontseptsiyu Novoyi ukrayinskoyi shkoli / Pedrada Retrieved from: http://www.pedrada.com.ua/article/2372-ad-fontes-pro-kontseptsyunovo-ukransko-shkoli

17. Tkachenko V.P. (2019). Sistema osilti v sotsialno-ekonomichnomu rozvitku krayini / V.P. Tkachenko, T.V. Vilkhova // Filosofsko-svitoglyadni ta kulturoiogichni konteksti neperervnoyi osviti: materiali mizhnarodnoyi naukovo-praktichnoyi konferentsiyi. p. 50-52.

18. Antonyuk O. Menedzhment $\mathrm{v}$ osvityanskiy sferi: kontseptualni zasadi / O. Antonyuk - Retrieved from: http://www.perconal.in.ua

19. Dzvinchuk D. (2003). Derzhavne upravlinnya osvitoyu v Ukrayini: tendentsiyi i zakonodavstvo. - K.: ZAT "Nichlava",- p. 239.

20. Krisyuk S.V. (2009). Derzhavne upravlinnya osvitoyu / S.V. Krisyuk // Navchalniy posibnik dlya sluhachiv, aspirantiv, doktorantiv spetsialnosti "Derzhavne upravlinnya osvitoyu". - K.: NADU. - p. 220.

21. Knishnik S.(2017). Transformatsiya sistemi osviti v Ukrayini / S. Knishnik // Efektivnist derzhavnogo upravlinnya. - Vol. 4 (53). - Part. 1. - p. 48-55.

22. Lugoviy V.I. (2008). Upravlinnya osvitoyu / V.I. Lugoviy // Entsiklopediya osviti. - K.: APN Ukrayini, Yurinkom Inter, - p. 944-945.

23. Lukina T.O. (2004). Derzhavne upravlinnya yakistyu zagalnoyi serednoyi osviti v Ukrayini: monografiya / T.O. Lukina. - K.: NADU. p.292.

24. Sychenko V.V. (2008). Derzhavna politika integratsiyi vischoyi osviti do Evropeyskogo osvitnogo prostoru / V.V. Sychenko. - Derzhava ta regioni: Seriya: Derzhavne upravlinnya. - 2008. - \# 4. - p. 183-188.

25. Fadeev V.I. (2009). Sistemni aspekti organizatsiyi upravlinnya osvitnimi resursami VNZ / V.I. Fadeev // Problemi suchasnoyi pedagogichnoyi osviti Ser. Pedagogika i psihologiya. - Zb. Statey. - Yalta: RVV RVNZ KGU.- p. 54-58.

26. Byudzhet na osvitu v 2018 rotsi zris na 53 mlrd grn / NUSh. Retrieved from: https://nus.org.ua/news/byudzhet-na-osvitu-v-2018-rotsi-zrist-na-53mlrd-grn/ 


\section{Відомості про авторів / Information about the Authors}

Вільхова Тетяна Володимирівна: Комунальний заклад вищої освіти «Дніпровська академія неперервної освіти», вул. Володимира Антоновича 70, м. Дніпро, 49006, Україна

Tetiana Vilkhova: Communal Institution of Higher Education «Dnipro Academy of Continuing Education», st. Antonovich, 70, Dnipro, 49006, Ukraine

ORCID.ORG/ 0000-0003-3087-6532

\section{E-mail: vilkhova@dano.dp.ua}

Москалець Михайло Миколайович: Комунальний заклад вищої освіти «Дніпровська академія неперервної освіти», вул. Володимира Антоновича 70, м. Дніпро, 49006, Україна

Mikhailo Moskalets: Communal Institution of Higher Education «Dnipro Academy of Continuing Education», st. Antonovich, 70, Dnipro, 49006, Ukraine

\section{ORCID.ORG/ 0000-0003-3079-158X}

\section{E-mail: m_moskalets@ukr.net}

Рибкіна Світлана Олексіївна: Дніпровський державний аграрноекономічний університет, вул. Сфремова, 25, м. Дніпро, 49600, Україна

Svitlana Rybkina: Dnipro State Agrarian and Economic University, st. Efremova, 25, Dnipro, 49600, Ukraine

ORCID.ORG/ 0000-0002-1063-6462

E-mail: kafedramo1@gmail.com 